\title{
The Romanian Music Scene. The Production, Distribution and Consumption of Pop Music in the Post-Socialist Period
}

\section{Anda Becut - Elena Trifan}

\section{Introduction}

Our article aims at exploring the evolution of the Romanian music industry, starting with the fall of socialism. We follow the dynamics of relationships in the production of music, from the viewpoint of lyrics, composition, producers and record labels. We shall offer an overview of the Romanian popular music industry in relation with technological and social changes.

The topic of popular music has been understudied in the Romanian context. There are few, but important, studies regarding the Romanian music in the socialist period, concerning the nationalist festival "Cântarea României" ${ }^{1}$ and in the post-socialist period, focusing on underground music ${ }^{2}$, manele/turbo folk ${ }^{3}$ or folk music ${ }^{4}$. Our paper is part of ongoing research which tends to fill the gap in research about music in post-socialist countries, concerning mainstream popular music, defined as pop music, which is played on the radio and on dance floors.

The importance of the topic resides in statistical studies - according to the Cultural Consumption Barometer from 2012 and 2015, although the most listened to genre is traditional folk music, the second is Romanian pop and easy listening, which is the first among young audiences. The public falls under the cultural univorism category, most people listening to only one category of music and having a tendency towards listening to music with Romanian lyrics. ${ }^{5}$

\footnotetext{
${ }^{1}$ A. Giurchescu, "The Power of Dance and Its Social and Political Uses," Yearbook for Traditional Music, no. 33 (2001): 109-121.

${ }^{2}$ R. Nagy and C. Plecadite, "Consuming Electronic Music in Bucharest: 'Low-Profile' Locations and Their Public," Ethnologia Balkanica, no. 10 (2007): 317-334.

${ }^{3}$ M. Beissineger et al., Manele in Romania: Cultural Expression and Social Meaning in Balkan Popular Music (New York and London: Rowman\&Littlefield, 2016).

4 A. Urdea, "Folklore Music on Romanian TV. From Socialist Television to Private Channels," Journal of European Television, History and Culture 5, no. 5 (2014); S. Rădulescu, "Traditional Musics and Ethnomusicology: Under Political Pressure: The Romanian Case," Anthropology Today 13, no. 6 (1997): 8-12.

5 C. Croitoru and A. Becuț, Barometru de consum cultural 2012 (București: Pro Universitaria, 2014).
} 
Moreover, listening to music is one of the first domestic cultural activities for youngsters, who mostly listen to music on their PC, smartphone, or tablet. For example, in $2012,40 \%$ of respondents obtained their music online, compared to 2006, when only $3 \%$ of them downloaded music. ${ }^{6}$

Our research was designed around the following research questions:

- How are the production, distribution, and promotion relationships being reshaped and restructured during the transition and capitalist period?

- How is the new artist envisaged by public discourse?

- How is the musical product reshaped and re-imagined?

In our paper, we focus on the dynamic of the Romanian music industry during the post-socialist period (1990-2017), which can be segmented into three other periods, according to the evolution of the production, distribution and consumption of music, and also according to the genres of music preferred by the audience. These periods are the early 1990s, the 2000s and the 2010s, all three marked by transitions in society (from communism to democracy) and economy (from the socialist to the market economy), by changes in the lifestyle and tastes of listeners and by the effects of new technologies and new media.

We identified the features of the three analysed periods from the viewpoint of music production (the music media, from magnetic tape to MP3), music distribution (how the audience had access to music - in the street, in specialised shops or online, in concerts or festivals, or on radio and TV), as well as from the viewpoint of the artists-audience relation (direct contact, through concerts and fan clubs or indirect contact, via mail or Internet).

There is one dominant music genre preferred by most of the Romanians - traditional folk music - but we shall focus on the second top most preferred genre: pop music and easy listening, with a particular attention paid to the dance trend. We are interested in these genres because they reflect changes in the tastes and lifestyles of Romanians during the transition period and also because they have remained unstudied by the social sciences scholars in Romania.

We focused particularly on two types of dance music bands, one which expressed its roots in traditional folk music and one with roots in the hip-hop and urban culture trend. Both of them are boy bands, and they are representative of the trend in the Romanian music scene which reflects the tension between rural and urban culture, between old and new, between communist and postcommunist culture.

${ }^{6}$ Ibid. 


\section{Methodology}

We propose an ethnographical approach in understanding the transformation in the Romanian music industry during the last 25 years. Drawing from DeWalt, DeWalt and Wayland's ${ }^{7}$ classification of observational methods, we argue that the best approach in this case is passive observation, which implies the bystander role of the researcher. The main reason resides in the characteristics of the subject researched, which is not a defined place in space and time, but rather addresses a long period of time, a lot of actors, and many spaces. The second reason was more practical; a complete immersion is not necessary, because both the researchers are Romanian citizens and they are accustomed to the language and regional habits. Therefore, the first step we undertook was an analysis of statistical data regarding music preferences that are relevant at national level, available from 2005, and gathered annually for the Barometer of Cultural Consumption in Romania. Another set of data was the evolution of creative production: the number of holograms and the number of representatives in the industry. The next step was an analysis of the representatives involved, using observational methods - artists, composers, producers, record labels, music products. The information gathered was discussed in interviews with important representatives in the development of the music industry, focusing on their observations regarding the evolution of the musical industry, as well as on their personal experience within it.

\section{Music and Dance: Concepts and Approaches}

In order to understand the features of the Romanian music industry, we need to present a general framework of social theories and concepts which might explain the changes identified in the analysed period. Speaking about the local context of music production and distribution, some authors use the concept of music scene, in order to "designate the contexts in which clusters of producers, musicians, and fans collectively share their common musical tastes and collectively distinguish themselves from others." ${ }^{8}$ The concept of a music scene was also used with the sense of "subcultures", ${ }^{9}$ but in this paper we shall use it to express a certain phase in the music production process which surpasses the industry, dominated by big players such as foreign music corporations or Romanian recording houses.

\footnotetext{
${ }^{7}$ K. M. DeWalt, B. R. DeWalt, and C. B. Wayland, "Participant Observation," in Handbook of Methods in Cultural Anthropology, ed. H. R. Bernard (Walnut Creek, CA: AltaMira Press., 1998), 259-299.

8 A. Bennett and R. Peterson, Music Scenes: Local, Translocal and Virtual (Nashville: Vanderbilt University Press, 2004), 1.

9 Ibid., 3 .
} 
We shall present the Romanian music scene as a reflection of the everyday life of music communities very much imbedded in local culture and its transition to the virtual scene. We consider that in Romania there is a music scene corresponding to each of the analysed period. Thus, the early 1990s corresponded to a music scene strongly influenced by the type of production used during the socialist period, dominated by the same tastes. The 2000 s are marked by the slow influence of foreign trends in music styles and the business, and the 2010s can be characterised by the internationalisation of productions and tastes.

The relationship between music and dance is complex and aesthetic movement helps to incorporate the sounds and rhythms of the music. A study on Led Zeppelin showed that the posture and movement of rock artists are essential for expressing the band's identity and their message and "the music as kinetic in that the performance is produced through 'sonoric gestures'."10

The concept of "dance music" has changed since 1970, when it was associated with the disco culture and is relevant for the relationship between this music genre and technology. ${ }^{11}$ According to Bennett, dance music has roots both in "house" and "techno", during the period of 1970-1990, when music makers used computers and technology in order to mix tones and create new ones. In this new process of music invention, the digital revolution had a remarkable influence, because computers could store and reproduce sound more accurately than the old analogue devices.

This allowed the transformation of the DJ's role from music player to music artist and stimulated the rise of the "club cultures". According to Bennett, the concept was introduced by Thorton "in an attempt both to rethink the subculture theory and to illustrate something of the stylistic heterogeneity of the British dance club scene of the1990s." 12

In dance club culture, the identity of young people is produced and performed. Music and dance became an instrument of self-definition and of communication to others, and they reflected the set of values to which individuals consent. According to Joanna Hall, a specific combination of music and dance is relevant for club-goers' construction of subjectivity. ${ }^{13}$ In her study, she highlighted the importance of music and dance in class and gender distinction and the relationship between the clubber, the dance and the genre of music.

\footnotetext{
${ }^{10}$ S. Dodds, "Bellowhead: Re-entering Folk through a Pop Movement Aesthetic," in Bodies of Sound, eds. S. Dodds and S. C. Cook (London: Ashgate, 2013), 32.

11 A. Bennett, Cultures of Popular Music (Philadelphia: Open University Press, 2001), 118.

12 Ibid., 125.

${ }^{13}$ J. Hall, "Rocking the Rhythm: Dancing Identities in Drum'n'Bass Club Culture," in Bodies of Sound, eds. S. Dodds and S. C. Cook (London: Ashgate, 2013), 104.
} 
The link between music and dance became important in studies interested in working-class subcultures and youth. "While dancing is marginalized in the dominant cultural tradition, it is a central interest to these structurally marginal groups whose ideas and practices are generally seen as (morally) suspect (sex, drugs and rock'n' roll)."14

In the following paragraphs, we shall present the Romanian music scene and how music and dance can express youth identity during the transition period, marked by the rural-urban culture tension. The tastes and lifestyles performed in the Romanian club culture highlight the pressure for social and class distinction in a period when the hierarchies of values are contested and redefined.

\section{The Early 1990s}

At the beginning of the 1990s, popular music was represented by easy-listening performers, who sang compositions of well-known composers from the socialist period. There was only one record label, named Electrecord, which was founded in 1932 by private investors. During the socialist period, it was nationalised and it became the only record label in Romania. Another important component in popular music were the easy listening festivals like The Golden Stag or Mamaia, also founded in the socialist period, which continued to be popular and to promote the same genre of music in the early 1990s. The Golden Stag was staged in the city of Brașov for the first time in 1968, in a period known as a more relaxed part of the socialist regime in Romania, ${ }^{15}$ and it was an international music festival. The Golden Stag had a short life during the socialist period (1968-1971), it was revived in 1992 by the municipality of Braşov. Meanwhile, the Mamaia Festival, set up at a sea-side resort which gave its name to the festival, was founded to promote the national easy-listening music. It also had a short interruption during the socialist period, from 1971 to 1983, and it also continued to engage Romanian artists with their audiences until 2010.

As far as the audio-visual promotion space is concerned, the situation is similar. During the communist regime, there was only one television - the National Romanian Television, and one national radio company - widely known as Radio Romania (both of them were state-owned companies and merged in 1956 in a new entity, the Romanian Radio-television). According to our archive research and interviews, they also promoted the easy listening artists.

${ }^{14}$ H. Thomas, Dance, Modernity and Culture (London and New York: Routledge, 2005), 8.

15 A. Matei, "The Golden Stag Festival in Ceausescu's Romania (1968-1971)," View Journal of European Television History And Culture, (2012). 
Another important aspect that characterised the music industry in the 1990s was the lack of any copyright laws. The main physical medium of distribution was the audio tape sold informally, "at the street corner", by the so-called tarabagii [street vendors]. When a person got hold of a tape, they would copy and multiply it, then sell it without any legal problems. Moreover, if a music artist wanted to be known by the public, they had to convince the street vendor to accept their tape and to play it in the public space to receive public recognition. The street vendor would receive a part of the selling price. This type of illegally regulated market was characteristic for this period in other industries and in former socialist countries. ${ }^{16}$

\section{The 2000s Period}

At the end of the 1990s, especially after 1996 when the copyright law was passed, a lot of boy- and girl bands conquered the charts and airtime with catchy rhythms and easy-to-remember lyrics about love, fun, and parties. Most of the bands were friends or family enterprises, and most of the singers were very young. We will present a case study of one music enterprise that was developed at the end of the 1990s. Generația nouă [The New Generation] was an organisation that promoted young, emerging dance bands, with a project named $K 1 .{ }^{17}$ They engaged up to thirty-five bands in their hayday, and employed one hundred and twenty people. Our informant was one of the founding members. He recollects that at the beginning:

I was the person who was good at everything, recording, compositions, management, I created the first legal copyright contract, I was the impresario, the producer, I handled licenses, it was like discovering oil. (Music entrepreneur, 42 years old)

This was the case for many other bands, as the band members would design their own costumes and their friends or family were their managers. Most of the compositions were also their own or their families'. The best example is the Andre band, which consisted of two girls, one of them under-aged, where both fathers handled the composition, management and clothing. The same goes for Simplu,

\footnotetext{
${ }^{16}$ See C. Humphrey, “Traders, 'Disorder', and Citizenship Regimes in Provincial Russia," in Uncertain Transition: Ethnographies of Change in the Postsocialist World, ed. M. Burawoy (Boston: Rowman \& Littlefield Publishers, 1999), 19-52; C. Humprey, The Unmaking of Soviet Life: Everyday Economies after Socialism (London: Cornell University Press, 2002).

${ }^{17}$ It stands for "(all) like one", similar to "all for one", from the popular phrase "One for all, all for one".
} 
a band started at the beginning of the 2000s: they would choose their clothes themselves, write their own lyrics and choreograph their own dance moves.

Their concerts gathered crowds of fans and their success encouraged many teenagers to start their own bands:

We used to receive hundreds of letters, we had three persons employed to open the letters and the presents, and another one to compose the answers. (Music entrepreneur, 42 years old)

In terms of distribution, it was the transition period from tapes to CDROMs. Due to the enforcement of the copyright law, it was a period of huge sales and the production of physical music media, therefore the street vendors of the early 1990s turned into professionalised stores. Another important change determined by the emergence of copyright law was the development of record companies. Most of them were local enterprises, like Generația Nouă, Nova Music, or Cat Music.

Another important stage in the development of the Romanian music industry was the emergence of private TV and radio channels. Amerom Canal 38 is one of the first major audio-visual actors in the development of the music industry, through a music TV show that aired music genres different from those promoted by the previous institutions (dance, hip-hop, rock). However, the most important actor of the audio-visual sphere in the development of the music industry was Atomic TV, a music-dedicated TV channel that sponsored Romanian artists to produce music videos. This decision was made because almost none of bands or singers had a music video, let alone a sufficient number of music videos to cover the broadcast time of a TV channel.

\section{The 2010s Period}

Along with the growing access to the Internet and the emergence of digital formats distributing musical products, record sales started to fall - the number of holograms (a mark of copyright) dropped significantly from 13 million in 2010 to 4 million in 2014 (according to ORDA ${ }^{18}$ records). Similarly, the domestic and foreign CD market contracted (according to $\mathrm{INS}^{19}$ ). Therefore, in the late 2010s, the main stream of distribution became digitalized.

18 The Romanian Copyright Office

19 National Institute of Statistics 
Most of the popular music bands of the late 1990s split up, with some of the members starting solo careers, while others becoming music producers or opening different enterprises.

With the growing influence of YouTube as the main medium of distribution, record labels lost their strong position in the management of artists, because most of the emerging artists would promote themselves. However, during our interviews this episode was described as a brief period of independence from the large record companies, as the latter had started to develop their own YouTube channels or apps (like Electrecord) and many independent music producers released music videos in collaboration with record labels. For example, $\mathrm{HaHaHa}$ production, an enterprise developed by Smiley, a member of Simplu, a popular band at the beginning of the 2000s which developed independent musical acts, started collaborating with Cat Music, one of the biggest record labels in Romania.

During this period, the Romanian music industry became more professionalised. While at the beginning of the 2000s, the bands were dealing with music, lyrics, clothing, and choreography, now teams of professionals worked for the record labels to produce entire musical acts.

There are few specialised stores selling CDs, and the more frequent places where one can buy a CD with mainstream Romanian music are gas stations. An member of the music industry stated that although the record labels still release albums in physical format, this only represents a popularisation event, while the main distribution environment is online - YouTube and streaming services.

And, as sales of record dropped, most of the YouTube videos have commercial product placement, and in some cases the entire song represents a commercial brand - for example the song "Ofcorso" by Corina and Connect-R that promoted the ice cream brand "Corso".

Another consequence of declining CD sales is that live performances were the main source of income for artists. While a dozen artists manage to have concerts with an entrance fee, most artists depend on various forms of institutional support from authorities or private entities that organise festive days with musical acts - municipal events, spring festivals, etc. - or at promotional events organised by big brands.

The relationship with the fans has also changed, from bags of letters of the 2000s to communication through social networks. Each artist has a social network page (usually Facebook or Instagram) where they most often communicate directly with their followers.

During this period, the style known as Romanian popcorn - Romanian club music with English lyrics - gained international momentum. Inna and Eduard Mayo, and other artists, enjoyed sales and tours in many other countries. Eduard 
Mayo won the American Billboard Award for "top dance song" of the year in 2011 for "Stereo Love", ${ }^{20}$ while Inna won the US Billboard's No. 1 spot, has over $150 \mathrm{~m}$ YouTube views and more than two million Facebook friends worldwide. ${ }^{21}$

\section{Conclusions}

The dynamic of the music industry in the period analysed was influenced by changes in Romanian society and economy. The music scene was marked by a tension between the old and new values with regard to the market and audience orientation, but also regarding the artistic content and the social message of the music. We identified the development of the entrepreneurial spirit among artists and their social group (friends and families) and the rise of the DYI (Do It Yourself) culture in the artistic environment. While in the first period of post-socialism many of the music activities remained informal, the approval of the copyright law marked the transition to the formal and legal structures of the Romanian music industry.

The need for liberty after such a long period of oppression and censorship translated into a no-rules trend and emphasis on freedom of choice, not only in the songs of the artists, but also in their appearance and performance. Dance very well expressed the explosion of energy and the most successful music bands combined dance and music, with the aim to attract audience attention and interest. This was a clear rupture from the old style of making and performing music during the communist period. The rural-urban tension was reflected in two trends in Romanian music, one using the nationalist spirit and folk roots and the other expressing the western fashion and sub-culture lifestyles. The development of new technology and new media has had a great influence on the dynamic of Romanian music industries and their recent success abroad.

\section{The Romanian Music Scene. The Production, Distribution and Consumption of Pop Music in the Post-Socialist Period}

\section{Abstract}

Our paper investigates the emergence of pop music in Romania against the background of the demise of state socialism and the implementation of neoliberal policies after 1989.

\footnotetext{
${ }^{20} \mathrm{http} / / / \mathrm{www}$. independent.co.uk/arts-entertainment/music/romanian-sound-takes-over-dancemusic-scene-2293332.html

${ }^{21} \mathrm{http} / /$ www.theguardian.com/music/2011/may/20/new-band-inna
} 
Romanian pop music is the most listened to genre among young people nationwide in Romania. The paper traces the evolution of the Romanian musical industry from a single state-owned label, Electrecord, during the socialist period, to the private initiatives, large or small, of post-socialism. We argue that the development of the Romanian pop music industry is tightly linked with particular processes of Romanian post-socialism. Hence, analysing this development enables us to shed light upon the specificities of post-socialism in Romania (but also in the broader Eastern European context). Furthermore, the paper delineates the relationship between pop music in Romania after 1989, post-socialism and global neoliberalism as a hegemonic discourse.

In the late 1990s and early 2000s, Romanian pop music meant private enterprises promoting teen stars playing simple compositions and improvised music videos produced on a low budget, dedicated exclusively to a Romanian audience, whereas more recently pop songs by Romanian stars have gained international recognition, and entered the international charts. Thus, Romanian pop music seems to portray the ethos of neoliberalism as described by Comaroff \& Comaroff, ${ }^{22}$ with wealth being attained almost miraculously.

\section{Hudební scéna v Rumunsku. Produkce, distribuce a spotřeba pop music v období post-socialismu}

\section{Abstrakt}

Článek zkoumá transformace populární hudby v Rumunsku na pozadí zániku státního socialismu a v kontextu nástupu neoliberální politiky po roce 1989.

Rumunský pop je v rámci své země nejposlouchanějším žánrem mezi mladými lidmi. Studie zkoumá vývoj rumunského hudebního průmyslu od doby státního monopolního labelu Electrecord, dále v průběhu socialistického období až k post-socialistickým privatizačním tendencím. Autoři zde potvrzují sepětí vývoje rumunského průmyslu pop music s konkrétními procesy rumunského post-socialismu, přičemž pochopením těchto vazeb ukazují nejenom lokální trendy, nýbrž i obecnější principy platné pro celý východoevropský kontext. Dále studie popisuje kontury vztahu mezi rumunskou populární hudbou po roce 1989, post-socialismem a globálním neoliberalismem jako hegemonním diskurzem.

V pozdních devadesátých a po roce 2000 charakterizovala rumunskou popovou hudbu činnost soukromých firem, jež propagovaly dospívající hvězdy interpretující banální repertoár, stejně tak nízkorozpočtové improvizované hudební

${ }^{22}$ J. Comaroff and J. Comaroff, "Alien-Nation: Zombies, Immigrants, and Millennial Capitalism," South Atlantic Quaterly 101, no. 4 (2002): 779-805. 
videoklipy určené výlučně domácímu publiku. $V$ pozdějších letech získaly rumunské popové hvězdy mezinárodní význam, což ukazují renomované žebříčky popularity. V tomto smyslu rumunský pop zobrazuje étosu neoliberalismu - jak popisuje Comaroff a Comaroff: s téměř zázračným nárůstem bohatství.

\section{Keywords}

Romania; post-socialism; production; distribution; pop music; culture industry

\section{Klíčová slova}

Rumunsko; post-socialismus; produkce; distribuce; pop music; kulturní průmysl

\section{Anda Becut}

Department of Sociology

Faculty of Sociology and Social Work, University of Bucharest

Schitu Magureanu 9, 010181 Bucharest, Romania

anda.becut@culturadata.ro

\section{Elena Trifan}

Department of Sociology

Faculty of Political Science, SNSPA

Expoziției 30, 010324 Bucharest, Romania

trifan.elena@gmail.com 